\title{
WINE CONSUMPTION IN CHINA: PROFILING THE 21ST CENTURY CHINESE WINE CONSUMER
}

\author{
CONSUMO DE VINHO NA CHINA: \\ PERFIL MÉDIO DO CONSUMIDOR CHINÊS DE VINHO DO SÉCULO XXI
}

\author{
María Carmen García-Cortijo ${ }^{1}$, Emiliano C. Villanueva ${ }^{2 *}$, Juan Sebastián Castillo-Valero ${ }^{1}$, Yuanbo Li ${ }^{3}$ \\ ${ }^{1}$ Regional Development Institute, University of Castilla-La Mancha, Campus Universitario s/n, Albacete 02071 Castilla-La Mancha, Spain. \\ ${ }^{2}$ Department of Business Administration, Eastern Connecticut State University, 83 Windham Street, Willimantic 06226 Connecticut, USA. \\ ${ }^{3}$ School of Public Policy and Management, Tsinghua University, Beijing, 100084, P.R. China. \\ * Corresponding author: Tel: +1-860-465-0478, e-mail: villanuevae@easternct.edu
}

(Received 20.06.2019. Accepted 20.08.2019)

\section{SUMMARY}

This article determines the factors that influence Chinese wine consumption and, thus, contribute to define an average Chinese wine consumer profile for the years 2000 to 2014. The article proposes a model that explains the variations in the consumption of wine in China, because of traditional factors of the theory of demand (price of wine, income, and price of a substitute good), and sociodemographic factors (age, gender, marital status, level of education, geographical area, and tourism activities). The article reveals that an increased income, a married marital status, living in an urban area, and tourism activities, significantly and positively contributed to the increase of wine consumption in China. In addition, the article demonstrates that wine is not a substitute of beer in China, and that it is hard to associate an increase of wine consumption with the gender and the educational level of the average Chinese. In contrast, age negatively and significantly influenced the wine consumption in China, meaning that wine consumers are becoming younger.

\section{RESUMO}

Este artigo analisa os fatores que influenciam o consumo de vinho na China e, assim, contribui para definir um perfil médio de consumidor para os anos de 2000 a 2014. O artigo propõe um modelo que explica as variações no consumo de vinho na China, com base nos fatores clássicos da teoria da procura (preço do vinho, rendimento e preço de um bem substituto) e fatores sociodemográficos (idade, sexo, estado civil, grau de instrução, área geográfica e atividades turísticas). O artigo revela que um aumento do rendimento, o estado civil casado, viver numa área urbana e a presença de atividades turísticas contribuíram de forma significativa e positiva para o aumento do consumo de vinho. Além disso, o artigo demonstra que na China o vinho não é um substituto da cerveja, e que é difícil associar um aumento do consumo de vinho ao género e ao nível educacional do chinês médio. Em contraste, a idade influenciou, de modo negativo e significativo, o consumo de vinho na China, o que significa que os consumidores de vinho estão a tornar-se mais jovens.

Key words: wine, China, demographics, consumption.

Palavras-chave: vinho, China, demografia, consumo.

\section{INTRODUCTION}

In the Western World, wine is a symbol of culture, history, and even religion. Wine and wine culture have been a crucial part of Europe for thousands of years and have been exported to all over the world. While this brilliant and long lasting European wine culture is acknowledged, it may not be ignored the wine culture and history of China. China has a 6,000year history of grape growing and a 2,000-year history of wine making (Zhang et al., 2013). Since the Han Dynasty (206 B.C. -220 A.D.), when the Vitis vinifera was introduced to China from Central Asia (Wang and Huang, 2009), it has not been hard to find 
historical and cultural references of wine in China (Jenster and Cheng, 2008; Li and Bardají, 2017). The beginning of the modern Chinese wine industry was initiated by the establishment of the Changyu Company in 1892 by Zhang Bishi (1841-1916) in the coastal city of Yantai, Shandong (Mitry et al., 2009).

After a rapid economic growth of more than thirty years since the Reform and Opening Up Policy in 1978, China has become the world's second largest economy with a vast market size of 1.36 billion people. This dramatic development of the Chinese society stimulates both the production and the consumption of alcoholic beverage in China. Due to this economy's expansion, the improved living standard and the growing middle class, there was a rising trend in both the total alcohol consumption and the per capita wine consumption in China. Since the entry of China into the World Trade Organization (WTO) in 2001, which helped decline wine import tariffs, foreign wines began to enter the Chinese market at a fast pace (Chen and Lombaerde, 2013; Liu et al., 2013; Li and Bardají, 2017). It was hard to imagine that one day China would be one leading wine consumer. However, the fact is that in 2013, China had surpassed France as the world's largest red wine consumer with more than 1.8 billion bottles of red wines sold in its territory, and in 2015 China had been ranked the world's fifth largest market for all kinds of wines with a total consumption of 16 million hL (OIV, 2018).

Even though traditional alcohol beverages such as Baijiu (Chinese liquor of cereals) and beer occupy the traditional alcohol market and it is not normal to drink wines with traditional Chinese food, Chinese people started to learn more about grape wines in the past decade (Dewald, 2003; Lin and Tavoletti, 2013). Chinese consumers are influenced by a history, culture and values that are very different from those of a Western consumer (Taylor, 2014). But in recent years, as noted in Capitello et al. (2015) and Gómez et al. (2015), the Chinese wine consumption has undergone major changes underlying a modern Chinese consumer, who adopts the Western lifestyle, and prefers foreign products (Zhao and Belk, 2007; Li et al., 2011; Bi et al., 2012). Wine is a drink reflecting the expectations of this new consumer, generally a young consumer.

According to the OIV (2018), in 2017 world wine consumption increased with respect to the previous year due to the fact of increased consumption in the United States, China and Australia. With a total consumption of 32.6 million $\mathrm{hL}$ of wine in 2017 , the United States established itself for the sixth consecutive year as the world's largest consumer of wine, followed by France ( 27 million hL), Italy (22.6 million hL), Germany (20.2 million hL), and China (17.9 million $\mathrm{hL}$ ). The United States and China are the two main world economies, and they both drive the upsurge of consumption of wine in the world. However, it will be China that will become the main consumer before the year 2030 (ahead of the United States and France), and will boost world growth in the next 15 years (Baque et al., 2016) - Figure 1 and Table I.

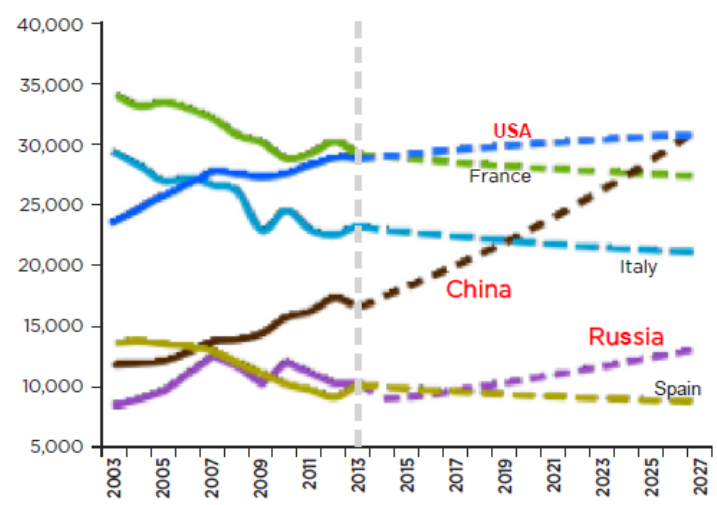

Figure 1. Changes in the consumption of wine, 2013 and expected for 2027, in thousands of hectoliters. Source: OIV (2018).

Mudanças no consumo de vinho, 2013 e esperado para 2027, em milhares de hectolitros. Fonte: OIV (2018).

Table I

Ranking of consumption of wine, 2013 and expected for 2027, volume per country

Ranking do consumo de vinho, 2013 e esperado para 2027, volume por país

\begin{tabular}{lcc}
\hline & $\begin{array}{c}\text { Ranking } \\
\mathbf{2 0 1 3}\end{array}$ & $\begin{array}{c}\text { Ranking } \\
\mathbf{2 0 2 7}\end{array}$ \\
\hline USA & 1 & $2(-1)$ \\
France & 2 & $3(-1)$ \\
Italy & 3 & $4(-1)$ \\
Germany & 4 & $5(-1)$ \\
China & 5 & $1(+4)$ \\
UK & 6 & $7(-1)$ \\
Russia & 7 & $6(+1)$ \\
Argentina & 8 & 8 \\
Spain & 9 & 9 \\
Australia & 10 & 10 \\
\hline
\end{tabular}

Source: OIV (2018). 
Wine consumption begins to be generalized in modern Chinese culture from the mentioned process of economic opening initiated in the 1980s, despite a long tradition in the cultivation of grapes and winemaking. As Campo (2018) points out, the success of wine in China is a reality. In addition to its huge and varied cuisine, its technology and the reputation of its citizens' workers, China has been positioning itself for some years also in the wine business. Its level of growth has experienced an annual increase of $10 \%$ in the last years, and its consumers have surpassed Japan, becoming the Asian country with the highest consumption of wine. The economic growth of the country and the interest for western wine and its tastes have led to this advance.

Drinking wine is a symbol of wealth, sophistication, and social status. It suggests a desirable social image, elegance, and worldliness (Liu and Murphy, 2007; Hu et al., 2008; Banks and Overton, 2010; Li et al., 2011). Chinese do drink wines for the celebration of important occasions such as the Chinese New Year and the Mid-autumn Festival when the Chinese lucky color red and the health benefit of wines are appreciated (Liu and Murphy, 2007; Muhammad et al., 2013). Health benefits and beauty purpose seem to be the first motivation of Chinese wine customers especially for the young female consumers (INS, 2017). In addition, wine can play an important role in the social connections as gift or banquet drink and luxury and expensive wines can show the generosity and richness of the host which caters to the Chinese traditional value "Mian Zi" (Liu and Murphy, 2007; Yu et al., 2009; Somogyi et al., 2011). If, in addition, the wine comes from a foreign country it is perceived as a luxury good of higher quality (Agnoli et al., 2014). Origin, brand, label (name, design, color, and image) are important when consumers purchase wines and French wines are considered in China as good wines with high quality (Wilson and Huang, 2003; Yu et al., 2009; Liu and Murphy, 2014; Xu et al., 2014; Tang et al., 2015). It is presented on important occasions or is used as a gift for parents or elderly relatives (Knight et al., 2008; Li et al., 2011).

Education also affects Chinese customers' wine purchase (Xu and Zeng, 2014). Since Chinese consumers are becoming more experienced, intrinsic cues such as taste, quality, and value-for-money are more valued for regular consumption (Liu et al., 2014). Besides wines from Bordeaux, Chinese consumers are more inclined to go for excellent wines from other wine regions of the world and getting more information from wine courses and websites (Masset et al., 2016). Enhanced customers' knowledge, product familiarity and emotional attachments to a specific wine region could contribute to the ethnocentrism of wine (Yang and Paladino, 2015).

As a response to the interest of wine and the desire of leisure, wine tourism has also developed in China (Zhang et al., 2013). The wine tourism includes visiting in wineries where the visitors may engage in several activities such as wine and food tasting, grape picking, and learning about wine culture. Many local Chinese governments intend to develop the wine tourism to support the local wine industries and to encourage the wine consumption of Chinese consumers.

This process of expansion of the Chinese wine industry, both from the perspective of production and consumption, makes the Chinese wine market very attractive for both local wineries and foreign producers. It is considered one of the markets with the greatest growth potential. China has become a player in world wine trade and is an important destination market for the main exporting countries (Mitry et al., 2009). In this sense, it is essential to know the demographic characteristics of the average Chinese consumer since it is the key to the success of any type of business.

Like what Villanueva et al. (2015) studied for the American wine consumer for the period 1995-2014, and what also Villanueva et al. (2017) did for the European wine consumer for a similar period, this article presents an empirical and econometric description of Chinese wine consumer's demographic and socioeconomic characteristics for the years 2000 to 2014. This article also follows a similar methodology as the articles mentioned before and uses for its analysis official Chinese Census variables (gender, age, education level, and household income), and Chinese wine industry variables (production, and wine consumption in volume and per capita). Wine has been dealt with as a homogeneous product, considering the total wine consumed in China during a year. Although there are many wine categories, unfortunately the Euromonitor (2018b) data sets presents "wine consumption volume" and "wine production volume" without differentiating any of these categories.

This article emphasizes wine consumer demographics as an area of research that provides a description of wine consumer profiles, mainly using psychographic variables and quantitative analysis. Some other research has been done referred to the description of wine consumer profiles and is mentioned as follows: the work done about China by Camillo (2012), Germany by Szolnoki and Hoffmann (2014) and Wiedmann et al. (2014), the United Kingdom by Ritchie (2007) and Phillips and Wilson (2016), 
France by Summerfield (2013), Spain by Gil and Sánchez (1997) and De-Magistris et al. (2014), Italy by Casini et al. (2009), Europe by Villanueva et al. (2017), Australia and New Zealand by Bruwer et al. (2002), Johnson and Bruwer (2003), Thomas and Pickering (2003) and Bruwer and Li (2007), South Africa by Ndanga et al. (2009), Argentina by Yvon (2007), Chile by Palma et al. (2014), and the U.S.A. by Hussain et al. (2006) and Villanueva et al. (2015).

The purpose of this article is to determine the factors that influence the Chinese wine consumer and, thus, contribute to define an average Chinese wine consumer profile for the years 2000 to 2014 . Following, the methodology is explained, then the data is presented, and an econometric model is specified and estimated to identify this profile, the results are shown, analyzed, and discussed, and finally, some conclusions are defined.

\section{MATERIAL AND METHODS}

In recent years there has been a change in the wine market in China linked to a better understanding of the industry, the increase in the purchasing power of the population, the process of urbanization, the entry into the W.T.O., and the growing interest in adopting Western habits of life (Liu et al., 2013; Labanda and Ruenes, 2016). In this section, the article proposes a model that explains the variations in the consumption of wine in China, because of traditional factors of the theory of demand (price of wine, income, and price of a substitute good), and sociodemographic factors (age, gender, marital status, level of education, geographical area, and tourism activities).

Thus, we can affirm that the main hypothesis $(\mathrm{MH})$ analyzed in this work and collected in the model affirms that:

MH: Wine consumption in China is a function of:

MH1: the traditional factors of demand, and

MH2: sociodemographic factors.

\section{Traditional factors of demand}

The traditional factors of demand are price, income, and price of a substitute good (beer). Next, the literature is reviewed on how wine consumption relates to each factor.

As Bi et al. (2012) points out, price is a fundamental influence in the choice of products. The price of wine in China is a critical factor when it comes to explaining demand. The results of the investigations of Liu and Murphy (2007) and Yu et al. (2009) show that consumers prefer to pay low prices for daily consumption, but higher prices for wine bought for gift purposes or special occasions, since it serves as a symbol of social status (Hu et al., 2008; Zhang et al., 2008; Somogyi et al., 2011).

Income is another variable to consider. In China, the increase in wine consumption is associated with the increase of incomes. In fact, higher income is one of the reasons for the expansion of the consumption of wine in China (Huang and Rozelle, 1998; Sun, 2009; Camillo, 2012International Wine and Spirit Research, 2013; Liu et al., 2013; Muhammad et al., 2013).

The price of a substitute good is another traditional factor considered in the theory of demand. Among the alcoholic beverages, the major competitors of wine are beer and spirits (ICEX, 2012; Wang, 2013), due to cultural and historical traditions. Although, as Mitry et al. (2009) point out, wine is a convincing substitute for beer and spirits in China. The price of beer is used.

\section{Sociodemographic factors}

The sociodemographic factors considered are age, gender, marital status, level of education, geographical area, and tourism activities.

Regarding age, Camillo (2012) found that the Chinese average wine consumer was between 19 and 35 years of age. In the same line, Li et al. (2011) and International Wine and Spirit Research (2013) point out that the main objective for wine sellers should be the members of the younger generation. In contrast, in other studies such as Liu et al. (2013) the results are inconclusive.

Regarding gender, a study by Liu et al. (2013) concludes that men are more likely to be wine buyers than women. However, Mitry et al. (2009) and Chen (2012) point to an increase in the consumption of wine by women, since gender equality continues to increase in China. In Liu et al. (2014) it is stated that women having more knowledge about wine will show a greater interest in wine consumption in the future than men (Li et al., 2011). Yet, in the study by Liu and Murphy (2007) it was deduced that the purchase of wine was considered a masculine role and that wine was perceived as more masculine than feminine (Bretherton and Carswell, 2001).

Marital status is another influencing factor in wine consumption (Camillo, 2012). Wine is considered a good disinhibitor and has a place in the intimacy of the couple (Nielsen Report, 2009). In addition, findings published in Journals of Gerontology indicate that couples who drink have a greater likelihood of a long-term happy marriage (Mercer, 2016). Other authors, on the other hand, point out that 
married men and women have lower rates of wine consumption compared to their unmarried counterparts (Temple et al., 1991; Chilcoat and Breslau, 1996; Bachman et al., 1997; Curran et al., 1998). In other studies, such as Liu et al. (2013), the results are inconclusive.

Chinese wine consumers are generally well educated (Gong et al., 2004; Balestrini and Gamble, 2006; Liu et al., 2014). In the last decade, educated young professionals have led to an expansion of wine consumption (Sun, 2009). The average consumer of wine in China tends to have university studies (China Economic Information Network, 2012).

The geographical area is another of the variables introduced in the model, distinguishing between rural and urban areas. Wine consumers are more likely to live in large urban areas such as Shanghai, Beijing, Guangzhou, Chengdu, and Shenzhen (Li et al., 2011; International Wine and Spirit Research, 2013). As noted in Lin and Wang (2010), Agnoli et al. (2014), and Capitello et al. (2015), there are important differences between people living in urban areas and in rural areas; the former is related to modernity, which in China leads to the consumption of foreign products, and the latter is linked to traditional consumption patterns. In addition, as Ripari (2005) points out, the difference in income between the urban and rural sectors is important. The changing landscape of the Chinese population from rural to urban households with better access to consumer goods, together with higher disposable income and the rise of the middle class, provides the basis for continued growth in the Chinese wine market (Huang and Rozelle, 1998).

The last factor considered in the model is tourism activities (Hall, 2000; Charters and Ali-Knight, 2002; Getz and Brown, 2006; Mitchell et al., 2012). Wine tourism is a form of tourism of special interest, and an important component of both the wine and tourism industries (Hall et al., 2000). Many wine regions and tourist destinations have realized that the benefits of wine tourism extend far beyond the winery door to practically all areas of the regional economy and into urban areas (Carlsen, 2004).

\section{Data and Empirical Model}

The database used includes the time series of wine consumption and its influencing factors (price of wine, income, price of beer, age, gender, marital status, level of education, geographical area and tourism activities) for the period 2000-2014 (15 years). For the development of the study, a model with two groupings of variables was specified. The first one uses the classical variables of a demand function, price of the good, income, and price of the substitute good. The second adds sociodemographic variables to identify the profile of the average consumer. Thus, to evaluate the effect of independent variables on wine consumption in China and to test the hypothesis, the following econometric model (Equation 1) has been proposed.

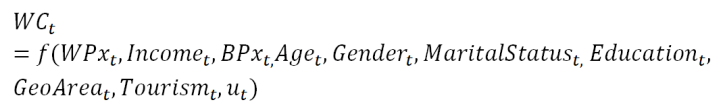

Eq. 1

where $u_{t}$ is the random disturbance that $u_{t} \sim N\left(0, \sigma_{u}^{2}\right.$

For the detection of the functional form of the model, the Box-Cox technique was used. As Arrufat (1997) states, this technique makes it possible to contrast hypotheses referring to the appropriate functional form. According to demand theory, an inverse relationship between the quantity demanded and the price of wine is expected, and a positive relationship with income, and a positive relationship with the price of beer are also expected. Regarding the sociodemographic variables, and as concluded from the review of the literature, the expectations may be non-conclusive. However, in general terms the Chinese consumer is identified as male, young, married, educated, resident in an urban area, and driven by tourism.

The variables specified for this study are shown in the Table II, and their descriptive statistics in Table III.

Once the variables are described, we turn to the estimation and validation of the model (Equation 2).

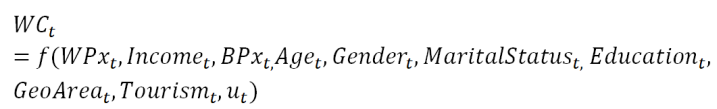

Eq. 2

First and to determine if it is necessary to apply some transformation on the dependent variable and/or the continuous independent variables, the Box-Cox procedure is applied. The models with a p-value higher than 0.05 are chosen. These models are associated with the LR test for the theta and lambda powers with values $-1,0,1$, and for the theta and lambda values lower than 0.05 , respectively (Tables IV and V). 
Table II

Variables of the Empirical Model

Variáveis do Modelo Empírico

\begin{tabular}{|c|c|c|}
\hline Variable & Tipology & Description \\
\hline $\begin{array}{l}\text { Dependent } \\
\text { Wine Consumption } \\
\text { (WC) }\end{array}$ & Continuous & $\begin{array}{l}\text { Wine Consumption in China (in Liters). } \\
\text { Source: China Sugar \& Liquor Yearbook (2003-2014); China Food Industry } \\
\text { Yearbook (2014-2015); UN Comtrade (2016) }\end{array}$ \\
\hline $\begin{array}{l}\text { Wine Price } \\
\text { (WPx) }\end{array}$ & Continuous & $\begin{array}{l}\text { Wine Unit Price per Liter (USD constant, inflation-adjusted, based on 2014, CPI } \\
\text { 1978=100) } \\
\text { Source: UN Comtrade (2016), National Bureau of Statistics of China (2016) }\end{array}$ \\
\hline Income & Continuous & $\begin{array}{l}\text { China GDP Growth Rate (\%, constant inflation-adjusted, based on 2014, CPI } \\
\text { 1978=100) } \\
\text { Source: National Bureau of Statistics of China (2016) }\end{array}$ \\
\hline $\begin{array}{l}\text { Beer Price } \\
(\mathrm{BPx})\end{array}$ & Continuous & $\begin{array}{l}\text { China Beer Unit Price (USD dollar per Liter, constant inflation-adjusted, based on } \\
\text { 2014, CPI 1978=100) } \\
\text { Source: UN Comtrade (2016), National Bureau of Statistics of China (2016) }\end{array}$ \\
\hline Age & Discrete & $\begin{array}{l}\text { 1: if the highest rate of variation of the population is between } 15-29 \text { years } \\
2: \text { if the highest rate of variation of the population is between } 30-39 \text { years } \\
3: \text { if the highest rate of variation of the population is between } 40-49 \text { years } \\
4: \text { if the highest rate of variation of the population is between } 50-59 \text { years } \\
5: \text { if the highest rate of variation of the population is within more than } 60 \text { years } \\
\text { Source: National Bureau of Statistics of China (2016) }\end{array}$ \\
\hline Gender & Discrete & $\begin{array}{l}\text { 1: if the highest rate of variation of the population is masculine } \\
0: \text { if the highest rate of variation of the population is feminine } \\
\text { Source: National Bureau of Statistics of China }(2016)\end{array}$ \\
\hline Marital Status & Continuous & $\begin{array}{l}\text { Chinese Married Couples } \\
\text { Source: National Bureau of Statistics of China (2016) }\end{array}$ \\
\hline Education & Continuous & $\begin{array}{l}\text { Number of students who return to China after graduation abroad } \\
\text { Source: National Bureau of Statistics of China (2016) }\end{array}$ \\
\hline $\begin{array}{l}\text { Geographical Area } \\
\text { (GeoArea) }\end{array}$ & Discrete & $\begin{array}{l}\text { 1: if most of the population resides in rural areas } \\
\text { 2: if most of the population resides in urban areas } \\
\text { Source: National Bureau of Statistics of China (2016) }\end{array}$ \\
\hline $\begin{array}{l}\text { Tourism Activities } \\
\text { (Tourism) }\end{array}$ & Continuous & $\begin{array}{l}\text { Number of Chinese Outbound Visitors (person-times) } \\
\text { Source: National Bureau of Statistics of China (2016) }\end{array}$ \\
\hline
\end{tabular}

\section{Table III}

Descriptive statistics

Estatisticas descritivas

\begin{tabular}{|c|c|c|c|c|c|}
\hline Continuous variables & Minimum & Maximum & Mean & SD & Obs \\
\hline Wine Consumption & $2.23 \mathrm{e}+010$ & $4.98 \mathrm{e}+010$ & $3.68 \mathrm{e}+010$ & $1.03 \mathrm{e}+010$ & 15 \\
\hline Wine Price & 0.822 & 4.22 & 2.24 & 1.36 & 15 \\
\hline Income & 7.30 & 14.2 & 9.71 & 1.91 & 15 \\
\hline Beer Price & 0.563 & 0.980 & 0.722 & 0.133 & 15 \\
\hline Marital Status & $7.8600 \mathrm{e}+006$ & $1.3469 \mathrm{e}+007$ & $1.0473 \mathrm{e}+007$ & $2.2109 \mathrm{e}+006$ & 15 \\
\hline Education & $9.12 \mathrm{e}+003$ & $3.65 \mathrm{e}+005$ & $1.13 \mathrm{e}+005$ & $1.24 \mathrm{e}+005$ & 15 \\
\hline Tourism Activities & $1.05 \mathrm{e}+007$ & $1.07 \mathrm{e}+008$ & $4.70 \mathrm{e}+007$ & $3.07 \mathrm{e}+007$ & 15 \\
\hline
\end{tabular}

Discrete variables

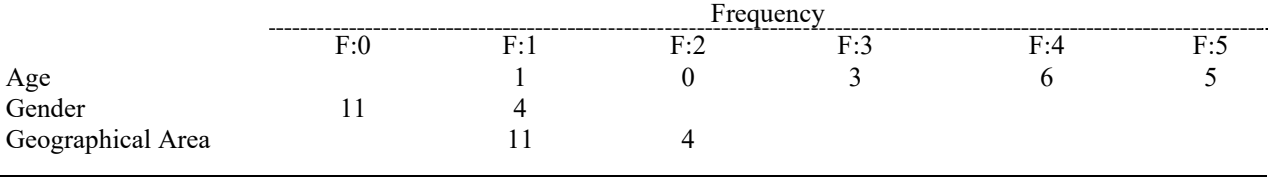




\begin{tabular}{|c|c|c|c|c|}
\hline & & $\begin{array}{l}J \\
L R\end{array}$ & & \\
\hline & LR statistic $\mathbf{H}_{\mathbf{0}}$ & Restricted & LR statistic & P-value \\
\hline & & log likelihood & chi2 & Prob $>$ chi 2 \\
\hline \multirow{3}{*}{$\begin{array}{l}\text { model(lhsonly) left-hand- } \\
\text { side Box-Cox model; }\end{array}$} & theta $=-1$ & -294.66808 & 19.18 & 0.000 \\
\hline & theta $=0$ & -286.76333 & 3.37 & 0.066 \\
\hline & theta $=1$ & -286.28394 & 2.41 & 0.121 \\
\hline \multirow{3}{*}{$\begin{array}{l}\text { model(rhsonly) right- } \\
\text { hand-side Box-Cox model }\end{array}$} & lambda $=-1$ & -297.26404 & 22.04 & 0.000 \\
\hline & lambda $=0$ & -293.35734 & 14.22 & 0.000 \\
\hline & lambda = 1 & -286.28394 & 0.08 & 0.780 \\
\hline \multirow{3}{*}{$\begin{array}{l}\text { model(lambda) both sides } \\
\text { Box-Cox model with } \\
\text { same parameter }\end{array}$} & lambda $=-1$ & -283.81744 & -4.70 & 1.000 \\
\hline & lambda $=0$ & -288.93533 & 5.53 & 0.019 \\
\hline & lambda $=1$ & -286.28394 & 0.23 & 0.632 \\
\hline \multirow{3}{*}{$\begin{array}{l}\text { model(theta) both sides } \\
\text { Box-Cox model with } \\
\text { different parameters }\end{array}$} & theta $=$ lambda $=-1$ & -283.81744 & -2.52 & 1.000 \\
\hline & theta $=1 \mathrm{ambda}=0$ & -288.93533 & 7.71 & 0.005 \\
\hline & theta $=$ lambda $=1$ & -286.28394 & 2.41 & 0.120 \\
\hline
\end{tabular}

Table V

Powers of the procedure of Box-Cox

Poderes do procedimento de Box-Cox

\begin{tabular}{|c|c|c|c|c|c|c|}
\hline & Powers & Std. Coef. & Err. & z & $\mathrm{P}>\mathrm{z}$ & Log likelihood \\
\hline $\begin{array}{l}\text { model(lhsonly) left-hand-side } \\
\text { Box-Cox model; }\end{array}$ & /theta & 0.5227056 & 0.2824196 & 1.85 & 0.064 & -285.07891 \\
\hline $\begin{array}{l}\text { model(rhsonly) right-hand-side } \\
\text { Box-Cox model }\end{array}$ & /lambda & 1.049204 & 0.1755811 & 5.98 & 0.000 & -286.24486 \\
\hline $\begin{array}{l}\text { model(lambda) both sides Box- } \\
\text { Cox model with same parameter }\end{array}$ & /lambda & 0.9198024 & 0.1694795 & 5.43 & 0.000 & -286.16912 \\
\hline \multirow{2}{*}{$\begin{array}{l}\text { model(theta) both sides Box-Cox } \\
\text { model with different parameters }\end{array}$} & /lambda & 1.005189 & 0.1741683 & 5.77 & 0.000 & \multirow{2}{*}{-285.07847} \\
\hline & /theta & 0.5249766 & 0.2920816 & 1.80 & 0.072 & \\
\hline
\end{tabular}

The Ramsey specification test was applied and, among those that resulted with a correct specification, the Corrected Determination Coefficient and the Mean Quadratic Error Root was obtained, selecting the model with the highest Determination Coefficient, lowest Error, and more coherent economic results (Table VI). 
Table VI

Global Model Selection.

Seleção Global de Modelos

\begin{tabular}{|c|c|c|c|c|}
\hline & \multicolumn{3}{|c|}{ Ramsey RESET test } & \multirow[b]{2}{*}{ Root MSE } \\
\hline & Test $\mathrm{H}_{0}$ : & $\begin{array}{l}\text { Ho: model has no } \\
\text { omitted variables }\end{array}$ & Adj R-squared & \\
\hline \multirow{2}{*}{$\begin{array}{l}\text { model(lhsonly) left-hand- } \\
\text { side Box-Cox model; }\end{array}$} & theta $=0$ & $\begin{array}{c}F(3,1)=0.46 \\
\text { Prob }>F=0.7619\end{array}$ & 0.9988 & 0.00974 \\
\hline & theta $=1$ & $\begin{array}{c}F(3,1)=0.86 \\
\text { Prob }>F=0.6394\end{array}$ & 0.9988 & $3.4 \mathrm{e}-08$ \\
\hline \multirow{2}{*}{$\begin{array}{l}\text { model(rhsonly) right- } \\
\text { hand-side Box-Cox model }\end{array}$} & lambda $=1$ & $\begin{array}{c}F(3,1)=0.86 \\
\text { Prob }>F=0.6394\end{array}$ & 0.9988 & $3.4 \mathrm{e}-08$ \\
\hline & lambda $=1.049204$ & $\begin{array}{c}F(3,1)=1.20 \\
\text { Prob }>F=0.5713\end{array}$ & 0.9988 & $3.4 \mathrm{e}-08$ \\
\hline \multirow{3}{*}{$\begin{array}{l}\text { model(lambda) both sides } \\
\text { Box-Cox model with } \\
\text { same parameter }\end{array}$} & lambda $=-1$ & $\begin{array}{c}F(3,1)=0.35 \\
\text { Prob }>F=0.8123\end{array}$ & 0.9932 & $2.2 \mathrm{e}-13$ \\
\hline & lambda $=1$ & $\begin{array}{c}F(3,1)=0.86 \\
\text { Prob }>F=0.6394\end{array}$ & 0.9988 & $3.4 \mathrm{e}-08$ \\
\hline & lambda $=.9198024$ & $\begin{array}{c}F(3,1)=0.46 \\
\text { Prob }>F=0.7640\end{array}$ & 0.9988 & $4.5 e-07$ \\
\hline \multirow{2}{*}{$\begin{array}{l}\text { model(theta) both sides } \\
\text { Box-Cox model with } \\
\text { different parameters }\end{array}$} & theta $=$ lambda $=-1$ & $\begin{array}{c}F(3,1)=0.35 \\
\text { Prob }>F=0.8123\end{array}$ & 0.9932 & $2.2 \mathrm{e}-13$ \\
\hline & theta $=$ lambda $=1$ & $\begin{array}{c}F(3,1)=0.86 \\
\text { Prob }>F=0.6394\end{array}$ & 0.9988 & $3.4 \mathrm{e}-08$ \\
\hline
\end{tabular}

The functional form for the model was that of (theta = lambda $=1$ ), so the specification of the model is described by the Equation 3 ).

$$
\begin{aligned}
W C_{t}= & \beta_{0}+\beta_{1} \text { WP }_{t}+\beta_{2} \text { Income }_{t}+\beta_{3} B P x_{t}+\beta_{4} \text { Age }_{t} \\
& +\beta_{5} \text { Gender }_{t}+\beta_{6} \text { MaritalStatus }_{t}+\beta_{7} \text { Education }_{t} \\
& +\beta_{8} \text { GeoArea }_{t}+\beta_{9} \text { Tourism }_{t}+u_{t}
\end{aligned}
$$

where $u_{t}$ is the random perturbance that $u_{t} \sim N\left(0, \sigma_{u}^{2}\right.$

The estimated model that has the following expression (Equation 4).

$$
\begin{aligned}
W C_{t}= & 2.63356 e^{10}+3.40024 \mathrm{e}^{9} \text { WP }_{t}+2.02583 e^{8} \text { Income }_{t} \\
& -1.71146 e^{10} B P x_{t}+-6.37433 e^{8} \text { Age }_{t} \\
& -2.92660 e^{9} \text { Gender }_{t}+648.534 \text { MaritalStatus }_{t} \\
& -25280.7 \text { Education }_{t}+9.29469 e^{8} \text { GeoArea }_{t} \\
& +243.087 \text { Tourism }_{t}
\end{aligned}
$$

The F-Snedecor, with p-value less than 0.05 and a Coefficient of Determination of $99 \%$ show the global capacity of all the explanatory variables of the model.
It is a model without multicollinearity, with a reciprocal condition number less than 50. The Harvey-Collier contrast indicated the stability of the coefficients estimated throughout the period with $\mathrm{P}(\mathrm{t}$ $(3)>1.8419)=0.162731$. On the other hand, the Breusch-Pagan contrast, with p-value higher than 0.05 , shows the absence of heterocedastity and the Durbin-Watson contract, with a value close to two, the absence of self-correlation; therefore, random perturbations maintain the same dispersion for all observations and a zero covariance. Finally, the residual sum of squares is close to zero (Table VII).

\section{RESULTS AND DISCUSSION}

The results of this estimation allow us to draw conclusions about the adequacy of the different factors and the results of their significance. Of the group of traditional variables all have been significant and with a positive sign, except the price of beer that, being significant, is accompanied by a negative sign. On the variable price of wine, it is of note that the Chinese consumer is not significantly influenced by the price increases to stop consuming. This result is linked to the fact that the consumption of wine is 
Table VII

Estimation Demand Model

Modelo de procura estimado

\begin{tabular}{|c|c|}
\hline & Coefficient \\
\hline const & $\begin{array}{l}2.63356 \mathrm{e}+010 * * * \\
(2.31394 \mathrm{e}+09)\end{array}$ \\
\hline Wine Price (WPx) & $\begin{array}{l}3.40024 \mathrm{e}+09 * * * \\
(3.60186 \mathrm{e}+08)\end{array}$ \\
\hline Income & $\begin{array}{l}2.02583 \mathrm{e}+08 * * * \\
(3.59710 \mathrm{e}+07)\end{array}$ \\
\hline Beer Price (BPx) & $\begin{array}{l}-1.71146 \mathrm{e}+010 * * * \\
(1.61533 \mathrm{e}+09)\end{array}$ \\
\hline Age & $\begin{array}{l}-6.37433 \mathrm{e}+08 * * * \\
(1.05061 \mathrm{e}+08)\end{array}$ \\
\hline Gender & $\begin{array}{l}-2.92660 \mathrm{e}+09 * * * \\
(1.59705 \mathrm{e}+08)\end{array}$ \\
\hline Marital Status & $\begin{array}{l}648.534 * * \\
(153.300)\end{array}$ \\
\hline Education & $\begin{array}{l}-25280.7 * * \\
(5928.76)\end{array}$ \\
\hline Geographical Area & $\begin{array}{l}9.29469 \mathrm{e}+08^{*} \\
(4.91398 \mathrm{e}+08)\end{array}$ \\
\hline Tourism Activities & $\begin{array}{l}243.087 * * * \\
(21.8631)\end{array}$ \\
\hline R-square & 0.999622 \\
\hline R-square (corrected) & 0.998773 \\
\hline $\mathrm{F}(9,4)$ & 43478.34 Value p (F) 1.29e-09 \\
\hline SCR & $3.4 \mathrm{e}-08$ \\
\hline RESET Contrast & $\begin{array}{l}\text { (squares and cubes) } \mathrm{F}=0.036310, \mathrm{p}=0.965 \\
\text { (only squares) } \mathrm{F}=0.092966, \mathrm{p}=0.78 \\
\text { (only cubes) } \mathrm{F}=0.102561, \mathrm{p}=0,77\end{array}$ \\
\hline Reciprocal condition number & 30.5063 \\
\hline Harvey-Collier $\mathrm{t}(3)=1.8419$ & $\mathrm{P}(\mathrm{t}(3)>1.8419)=0.162731$ \\
\hline $\begin{array}{l}\text { Heterocedasticity Contrast of Breusch- } \\
\text { Pagan }\end{array}$ & $\mathrm{LM}=11.855 \mathrm{P}($ Chi-square $(9)>11.855)=0.221608$ \\
\hline Durbin-Watson & 2.268731 \\
\hline
\end{tabular}

associated with a high purchasing power; the consumer prefers to opt for a higher price to demonstrate their social status or economic capacity. These results corroborate the work of $\mathrm{Hu}$ et al. (2008), Zhang et al. (2008), Somogyi et al. (2011), and Labanda and Ruenes (2016). The income variable shows that an increase in economic capacity leads to increased consumption of wine in China, and this is consistent to the work of Huang and Rozelle (1998), Sun (2009), Camillo (2012), Liu et al. (2013), International Wine and Spirit Research (2013), and Muhammad et al. (2013). On the other hand, the price of beer has been significant, but with a negative sign, which tells us that the wine, still, is not a real substitute for beer, contrary to the conclusions of Mitry et al. (2009) and Wang (2013), which point out that wine is a compelling substitute for beer and spirits in China. Even so, the June 2018 report of Euromonitor International (2018a) indicates that sales of total volume of beer fell both in 2016 and in 2017, with 2017 being the fourth consecutive year of decline. This was due to several factors, including the declining population of beer drinkers and changes in consumer lifestyles, such as increased consumption of alternative alcoholic beverages, such as wine.

The same report states that wine continues to expand its presence in China with stable growth of total volume in 2017.

Of the sociodemographic factors, age has been a significant variable, but with a negative sign. That is, the younger generations are presented as the main wine buyers. These results are the same as shown in Li et al. (2011), Camillo (2012), and International 
Li et al. (2011), Camillo (2012), and International Wine and Spirit Research (2013). In contrast, in other studies such as Liu et al. (2013) the results are inconclusive. The gender variable is negative and significant, which implies that being a man does not mean consuming more wine, contrary to the results of the studies done by Bretherton and Carswell (2001), Liu and Murphy (2007), and Liu et al. (2013). They concluded that a Chinese man is more likely to be a wine buyer than a woman. Mitry et al. (2009), Chen (2012) and Liu et al. (2014) indicate an increase in the consumption of wine by women due, on the one hand, to that gender equality continues to increase in China and, on the other hand, to the increase of their knowledge about wine. Marital status is also a significant and positive variable in wine consumption, like what is presented in Mercer (2016). Other authors, however, point out that married men and women have lower rates of wine consumption compared to their unmarried peers (Temple, 1991; Chilcoat and Breslau, 1996; Bachman et al., 1997; Curran et al., 1998). In other studies, such as Liu et al. (2013), the results are inconclusive. The level of education, although significant, obtains a negative sign, contrary to the profile given by different Chinese consumer studies (Gong et al., 2004; Balestrini and Gamble, 2006; Sun, 2009; China Economic Information Network, 2012; Liu et al., 2014). Regarding the differentiation of rural and urban regions, the model indicates that in urban areas they are more prone to consume wine, since these areas are linked to patterns of success and modernity, with better access to consumer goods, and more disposable income. This result follows those of Li et al. (2011), and International Wine and Spirit Research (2013). Even so, the last year's Euromonitor International report (2018b) indicates that in 2017 the decrease in demand in tier-one cities for wine forced manufacturers to seek growth in lower-level cities through the opening of stores specialized in beverages and the development of solid relationships with local retailers. Tourism has also been significant and positive, related to the growing interest in wine tourism (Hall, 2000; Charters and Ali- Knight, 2002; Getz and Brown, 2006; Mitchell et al., 2012).

In short, the consumption of wine in China, although linked to a higher level of income, is introduced with force in the country, reaching the younger generations, women, individuals with different academic degrees, and living in urban areas. Beer, in the period analyzed, is not a substantial substitute. Wine tourism play an important role in the increase of wine consumption.

\section{CONCLUSIONS}

This study attempts to describe the growing wine market of China identifying various factors for the increase in wine consumption, describing an average wine Chinese consumer. China does have a history and tradition for wine drinking and the booming wine consumption in China in recent years can be a comprehensive result of the fast-growing Chinese economy, improved standards of living, interest of the Western culture, and improved health and social reasons. China has recently been one of the most important wine markets in the world and the largest wine market in Asia, importantly contributing to the growth of the world's wine consumption. In the coming decade China will even become the first wine-consuming market.

With the development of an econometric model combining several influencing factors (wine price, income, beer price, age, gender, marital status, level of education, geographical area, and tourism) for wine consumption in China in the period 2000-2014, this article reveals that an increased income, a married marital status, living in an urban area, and tourism activities, significantly and positively contributed to the increase of wine consumption in China. In addition, the article demonstrates that wine is not a substitute of beer in China, and that it is hard to associate an increase of wine consumption with the gender and the educational level of the average Chinese. In contrast, age negatively and significantly influenced the wine consumption in China, meaning that wine consumers are becoming younger.

This article shows certain limitations. The data adopted are for the whole country of China, which is geographically huge and densely populated, without considering regional differences and development gaps. Hence more research in the topic is needed in the future, considering that the results of this study point to a wine consumption market segmented by territories (urban-rural) and income levels. 


\section{REFERENCES}

Agnoli L., Capitello R., Begalli D., 2014. Geographical brand and country-of-origin effects in the Chinese wine import market. J. Brand Mngt., 21, 541-558.

Arrufat, 1997. Técnicas econométricas para estimar funciones de demanda. Available at: http://www.aaep.org.ar/anales/works/works1997/arrufat.pdf

Bachman J.G., Wadsworth K.N., O’Malley P.M., Johnston L.D., Schulenberg J.E., 1997. Smoking, drinking, and drug use in young adulthood: The impact of new freedoms and new responsibilities. 264 p. Lawrence Erlbaum Associates Publishers, New Jersey.

Balestrini P., Gamble P., 2006. Country of-origin effects on Chinese wine consumers. Br. Food J., 108, 396-412.

Banks G., Overton J., 2010. Old world, new world, third world? Reconceptualizing the worlds of wine. J. Wine Res., 21, 57-75.

Baque G., Chollet P., Rippe-Lascout, 2016. Frente a la globalización del mercado del vino, Europa se dobla pero no se rompe. Publicaciones económicas de Coface, Madrid.

Bi X., Gunessee S., Hoffmann R., Hui W., Larner J., Ma Q.P., Thompson F.M., 2012. Chinese consumer ethnocentrism: A field experiment. J. Consumer Behav.,11, 252-263.

Bretherton P., Carswell P., 2001. Market entry strategies for western produced wine into the Chinese market, IJWBR, 13, 23-35.

Bruwer J., Li. E., 2007. Wine-Related Lifestyle (WRL) market segmentation: demographic and behavioral factors. J. Wine Res., 18, 49-66.

Bruwer J., Li E., Reid M., 2002. Segmentation of the Australian Wine Market Using a Wine-Related Lifestyle Approach. J. Wine Res., 13, 217-242.

Camillo A., 2012. A strategic investigation of the determinants of wine consumption in China. IJWBR, 24, 68-92.

Campo J., 2018. ¿Sabias que también se hace vino en China?. Available at URL:https://theluxonomist.es/2018/02/19/el-negocio-delvino-en-china/javier-campo-gonzalez.

Capitello R., Agnoli L., Begalli D., 2015. Chinese import demand for wine: evidence from econometric estimations, J. Wine Res., 26, 115-135.

Carlsen J., 2004. A Review of global wine tourism research. J. Wine Res., 15, 5-13.

Casini L., Rungie C., Corsi A.M., 2009. How loyal are Italian consumers to wine attributes? J. Wine Res., 20, 125142.

Charters S., Ali-Knight J., 2002. Who is the wine tourist? Tour. Manag., 23, 311-319.
Chen K., 2012. South China Quarterly U.S. Wine Promotion Report. U.S. Department of Agriculture, Foreign Agricultural Service, Gain Report Number CH1 1852.

Chen L., Lombaerde P., 2013. Reposicionamiento de los productos "hechos en China" en las cadenas de valor globales y regionales. In: La transformación de China y su impacto para Colombia. 107-141. Vieira E. (ed.), Colegio de Estudios Superiores de Administración, Bogotá.

Chilcoat H., Breslau N., 1996. Alcohol disorders in young adulthood: effects of transitions into adult roles. J. Health Soc. Behav., 37, 339-349.

China Economic Information Network, 2012. Chinese College Graduation Data. Available at: http://www.cei.gov.cn (accessed on 30.5.2018).

China Food Industry Yearbook, 2014-2015. Available at http://www.stats.gov.cn/tjsj/ndsj/2015/indexeh.htm.

China Sugar \& Liquor Yearbook, 2003-2014. Publication of China National Association for Liquor and Spirits Circulation.

Curran P., Muthen B., Harford T., 1998. The influence of changes in marital status on developmental trajectories of alcohol use in young adults. J. Stud. Alcohol, 59, 647-58.

De-Magistris T., Gracia A., Albisu L., 2014. Wine consumers' preferences in Spain: an analysis using the bestworst scaling approach. Span. J. Agric. Res., 12, 5-29.

Dewald B.W.A., 2003. Wine Consumption in Hong Kong. Int. J. Wine Mark., 15, 54-68.

Euromonitor International, 2018a. Beer in China. Available at: http://www.euromonitor.com/beer-in-china/report (accessed on 20.7.2018).

Euromonitor International, 2018b. Wine in China. Available at: http://www.euromonitor.com/wine-inchina/report (accessed on 2.7.2018).

Getz D., Brown G., 2006. Critical success factors for wine tourism regions: A demand analysis. Tour. Manag., 27, $146-158$.

Gil J., Sánchez M., 1997. Consumer preferences for wine attributes: a conjoint approach. Br. Food J., 99, 3-11.

Gómez L.M., Bacardí M., Caravalí N., Jiménez A., 2015. Consumo de bebidas energéticas, alcohólicas y azucaradas en jóvenes universitarios de la frontera México-USA. Nutr Hosp., 31,:91-195.

Gong W., Li Z.G., Li T., 2004. Marketing to Chinese youths: a cultural transformation perspective. Bus. Horiz., 47, 41-50.

Hall C.M., 2000. Wine tourism around the world. 368 p. Routledge, Abingdon.

Hall C.M., Longo A.M., Mitchell R., Johnson G., 2000. Wine tourism in New Zealand. In: Wine Tourism Around the World: Development, management and markets. 150176. Hall C.M., Sharples L., Cambourne B., Macionis N. (eds.), Elsevier Science, Oxford. 
Hu X., Li L., Xie C., Zhou J., 2008. The effects of countryof-origin on Chinese consumers wine purchasing behavior. J. Tech. Mngt. China, 3, 292-306.

Huang J., Rozelle S., 1998. Market development and food demand in rural China, China Eco. R., 9, 25-45.

Hussain M., Castaldi R., Cholette S., 2006. Determinants of Wine Consumption of U.S. Consumers: an Econometric Analysis. In: 3rd International Wine Business Research Conference, Montpellier.

ICEX, 2012. El mercado de vino en China. Available at: http://www.iberchina.org/files/china_vino_icex.pdf (accessed on 20.7.2018).

International Wine and Spirit Research, 2013. The World Wine and Spirits Market with a Look Forward to 2016. Vinexpo. Available at: https://www.infowine.com/docs/document144.pdf.

Jenster P., Cheng, Y.T., 2008. Dragon wine: developments in the Chinese wine industry. IJWBR, 20, 244-259.

Johnson T., Bruwer J., 2003. An Empirical Confirmation of Wine-Related Lifestyle Segments in the Australian Wine Market. Int. J. Wine Mark., 15, 5-33.

Knight J., Gao H., Garrett T., Deans K., 2008. Quest for social safety in imported foods in China: Gatekeeper perceptions. Appetite, 50, 146-157.

Labanda L., Ruenes G., 2016. El mercado de vino en China. Estudios de Mercado. ICEX.

Li Y.B., Bardají I., 2017. A new wine superpower? An analysis of the Chinese wine industry. Cahiers Agri., 26, 19.

Li J., Jia J., Taylor D., Bruwer J., Li E., 2011. The wine drinking behavior of young adults: an exploratory study in China. Br. Food J., 113, 1305-1317.

Lin H., Tavoletti E., 2013. The Marketing of Italian Wine Brands in China: The 'Mainstreaming' Approach. Transition St. R., 20, 221-237.

Lin X., Wang C.L., 2010. The heterogeneity of Chinese consumer values: A dual structure explanation. Int. J. Cross Cult. Manag, 17, 244-256.

Liu H.B., McCarthy B., Chen T.Z., Guo S., Song X.G., 2014. The Chinese wine market: a market segmentation study. APJML, 26, 450-471.

Liu H.B., McCarthy B., Chen T.Z., Zhou Z.Y., Song X.G., Guo S., 2013. Dynamics of wine consumption in China: an empirical study. In: Proceedings of the 27th Australian and New Zealand Academy of Management Conference. 216. ANZAM 2013, Hobart.

Liu F., Murphy J., 2007. A qualitative study of Chinese wine consumption and purchasing: Implications for Australian wines. $I J W B R$, 19, 98-113.

INS, 2017. How to enter the wine market in China. Available at: https://ins-globalconsulting.com/enter-winemarket-china- $2 /$.
Masset P., Weisskopf J.P., Faye B., Le Fur E., 2016. Red obsession: The ascent of fine wine in China. Emerg. Mark. Rev., 29, 200-225.

Mercer C., 2016. Drinking wine could be secret to happy marriage - study. Available at: https://www.decanter.com/wine-news/drinking-wine-

happy-marriage-study-323039/\#ZwBmQERtDVk5Ei3B.99 (accessed on 15.7.2018).

Mitchell R., Charters S., Albrecht J.N., 2012. Cultural systems and the wine tourism product. Ann. Tour. Res., 39, 311-335.

Mitry D., Smith D., Jenster P.V., 2009. China's role in global competition in the wine industry: A new contestant and future trends. IJWBR, 1, 19-25.

Muhammad A., Leister A.M., McPhail L., Chen W., 2013. The evolution of foreign wine demand in China. Aust. J. Agric. Resour. Econ., 58, 392-408.

National Bureau of Statistics of China, 2016. Available at: http://www.stats.gov.cn/.

Ndanga L.Z.B., Louw A., van Rooyen J., 2009. Increasing domestic consumption of South African wines: identifying the key market segments of the "Black Diamonds". $A A W E$, 41, Business.

Nielsen Report, 2009. Estudio de base sobre el consumidor español de vino con segmentación actitudinal de consumidores. Genoma del consumidor del vino en España. Available at: http://www.oemv.es/esp/caracterizacion-delconsumidor-espanol-de-vino-(genoma)-33k.php (accessed on 20.7.2018).

OIV, 2018. International Organization of Vine and Wine. Available at: http://www.oiv.int/ (accessed on 20.3.2018).

Palma D., Ortúzar J.D., Rizzi L., Casaubon G., Agosin E., 2014. Measuring consumer preferences using hybrid discrete choice models. $A A W E, \mathbf{1 3 7}$, Economics.

Phillips S., Wilson J., 2016. GAIN (Global Agricultural Information Network) Report: United Kingdom. Washington, DC: USDA Foreign Agricultural Service.

Ripari M., 2005. El nuevo consumo de China. Available at: http://www.alimentosargentinos.gob.ar/HomeAlimentos/Pu blicaciones/revistas/nota.php?id $=447 \quad$ (accessed on 3.7.2018).

Ritchie C., 2007. Beyond drinking: the role of wine in the life of the UK consumer. Int. J. Consum. Stud., 31, 534540 .

Somogyi S., Li E., Johnson T., Bruwer J., Bastian S., 2011. The underlying motivations of Chinese wine consumer behaviour. APJML, 23, 473-485.

Summerfield M., 2013. Wine drinking culture in France: a national myth or a modern passion? J. Wine Res., 24, 81-82.

Sun B.B., 2009. National Wine Market: People's Republic of China. U.S. Department of Agriculture, Foreign Agricultural Service. Gain Report Number CH9808. 
Szolnoki G., Hoffmann D., 2014. Consumer segmentation based on usage of sales channels in the German wine market. IJWBR, 26, 27-44.

Tang V.C.M., Tchetchik A., Cohen E., 2015. Perception of wine labels by Hong Kong Chinese consumers. WEP, 4, 1221.

Taylor R., 2014. The globalization of Chinese business: Implications for multinational investors. 323 p. Chandos Publishing, Oxford.

Temple M.T., Fillmore K.M., Hartka E., Johnstone B.M., Leino E.V., Motoyoshi M., 1991. A meta-analysis of change in marital and employment status as predictors of alcohol consumption on a typical occasion. Brit. J. Addict., 86, 1269-1281.

Thomas A., Pickering G., 2003. Behavioural segmentation: a New Zealand wine market application. J. Wine Res., 14, 127-138.

UN Comtrade, 2016. Available at: https://comtrade.un.org/.

Villanueva E., Castillo J.S., García-Cortijo M.C., 2015. Who is drinking wine in the United States? The demographic and socioeconomic profile of U.S. wine consumers (1972-2012). IFAMR, 18, 39-60.

Villanueva E., Castillo J.S., García-Cortijo M.C., 2017. Wine consumer profiles from producing and importing countries in Europe are different. Ciência Tec. Vitiv., 32, $115-125$

Wang Z., 2013. Market analyses and marketing strategies for imported wine in China market. $47 \mathrm{p}$. Master thesis for MIEB, Université de Strasbourg.

Wang S.Z., Huang P., 2009. Discussion on grape wine history in China. Liquor-making Sc.\& Tech., 11, 136-143.
Wiedmann K., Behrens S., Klarmann C., Hennigs N., 2014. Customer value perception: Cross-generational preferences for wine. Br. Food J., 116, 1128-1142.

Wilson I., Huang Y.L., 2003. Wine Brand Naming in China. Int. J. Wine Mark, 15, 52-63.

Xu P., Zeng Y.C., 2014. Factors that affect willingness to pay for red wines in China. J. Int. Consum. Mark., 26, 426439.

Xu P., Zeng Y.C., Song S.F., Lone T., 2014. Willingness to pay for red wines in China. J. Wine Res., 25, 265-280.

Yang Y., Paladino A., 2015. The case of wine: understanding Chinese gift-giving behavior. Mktg. Let., 26, 335-361.

Yu Y., Sun H.H., Goodman S., Chen S.W., Ma H.Q., 2009. Chinese choices: a survey of wine consumers in Beijing. IJWBR, 21, 155-68.

Yvon B., 2007. An overview of the wine market. What is the potential for Argentinean wines? Moet et Chandon Estate Wines, Asia-Pacific Division, Intl Wine Forum.

Zhang J., Casswell S., Cai H., 2008. Increased drinking in a metropolitan city in China: a study of alcohol consumption patterns and changes. Addiction, 103, 416-416.

Zhang Q.H.Q., Yuan J.X., Ye B.H.B., Hung K., 2013. Wine tourism phenomena in China: an emerging market. Int. J. Contemp. Hosp. Manag., 25, 1115-1134.

Zhao X., Belk R.W., 2007. Live from shopping malls: Blogs and Chinese consumer desire. ACR North American Advances. 